\title{
Unbearable Lightness: Some Modern Instances in Auden, Stevens and Eliot
}

Key words: light, shadow, Auden, Stevens, Eliot, ambiguity, transience

In our Western tradition it all begins with light, as the animating element of what had otherwise been merely 'waste and void': ‘And God said, "Let there be light”, and there was light' (Genesis 1: 2, 3). But this stupendous positive simultaneously implies its negative antithesis, the status quo ante of darkness which, if either momentarily or persistently restored, is worse because now comprising awareness of deprivation.

Before arriving at the authors indicated above I wish to touch on some others, who like them engaged in partially adversarial dialogue with a visionary tradition, whether conceived in religious or Romantic terms; in which dialogue, tropes of light are significant. Emily Dickinson, for example, their anachronistically Modernist precursor, powerfully evoked light's negative potential and its capacity to reveal absence rather than presence: ‘There’s a certain Slant of light/ Winter Afternoons - / That oppresses, like the Heft/ Of Cathedral Tunes' (J258 [F320A]). ${ }^{1}$ The 'Heavenly Hurt' administered here is glossed by another of her poems ruminating on an ultimately 'illegible' Creator: 'The Light His Action, and the Dark/ The Leisure of His Will' (J820 [F1113A]). The dynamic of 'Light' implies, therefore, the inertia of 'Dark'; and light as sign, not of divine presence but of the potential for divine absence, occurs also in Thomas Hardy’s 'Neutral Tones' (1867), where energies bleed away under an emblematically unsympathetic stage-lighting: 'And the sun was white, as though chidden of God'?

'God' and the meanings he endorses are resonant in absence for Dickinson and for Hardy; as Wallace Stevens would suggest, ${ }^{3}$ Jove's statue has been blown up and our sky reverberates with the ensuing emptiness. But 'Jove' is not the only missing monument; an adjacent, equally-vacated plinth once exhibited that 'Nature' previously evoked by 
mainstream Romantics as a consolingly available source of value ('Nature's self, which is the breath of God', wrote Wordsworth in The Prelude [1805 text], III. 221). On 14 April 1805 Coleridge, in Malta, mused thus in his Notebook:

In looking at objects of Nature while I am thinking, as at yonder moon dimglimmering through the dewy window-pane, I seem rather to be seeking, as it were asking for, a symbolical language for something within me that already and forever exists, than observing anything new. Even when that latter is the case, yet still I have always an obscure feeling as if that new phenomena were the dim awaking of a forgotten or hidden truth of my inner nature. ${ }^{4}$

This implicit congruence between objective 'Nature' and one’s 'inner nature', by means of which 'symbolical' connection is intuited to a 'hidden truth' that 'already and forever exists', is experienced more as a broken link, by my later examples. They, however, could be seen as merely expressing the same process negatively; for Dickinson's 'Slant of light' and Hardy's 'God-curst sun, and a tree’ alike deploy elements of an external scene to body forth the speaker’s ' 'inner weather' (Robert Frost's phrase), ${ }^{5}$ registering what her poem defines as Comment [SW1]: Edition needed in 'internal difference', as opposed to congruence.

'Dominus illuminatio mea' runs the inscription on Oxford University Press’s openedbook logo; but literature, unlike scholarship, thrives on the ambiguity of less-than-full illumination. In Coleridge’s passage above, phrases such as ‘dim-glimmering’, ‘dewy window-pane', 'obscure feeling' and 'dim awaking' stress the suggestive power of things half-sensed, half-lit. Michael Edwards has remarked that in prelapsarian Eden the impulse to imagine a world other than the given is inconceivable: ${ }^{6}$ creative writing vies with the Creator and originates, therefore, in distance from God. The oppressiveness of Dickinson's slant of light, linked as it is to the 'Cathedral Tunes' of religious observance, derives from a world negatively transfigured by the sensed inadequacy of such orthodox accounting. If knowledge 
of God makes poetry redundant, the poet is necessarily of the devil's party and perhaps her truest cry is for 'Less light! Less light!', reversing Goethe’s dying exclamation (Goethe himself, of course, was concerned to displace Newtonian theories of light by his own). To stay in mid-nineteenth-century New England, this was the implication of Nathaniel Hawthorne’s ‘Author’s Preface’ (actually written in old England) to The Marble Faun (1860): 'No author, without a trial, can conceive of the difficulty of writing a Romance about a country where there is no shadow, no antiquity, no mystery, no picturesque and gloomy wrong, nor anything but a common-place prosperity, in broad and simple daylight, as is happily the case with my dear native land' ${ }^{7}$

'[B]road and simple daylight' need not denote complete absence of that 'interest ${ }^{\text {' }}$ stipulated by Henry James, in a formulation cited more than once by W.H. Auden. Auden, addressing his new-found resting-place, 'sun-drenched' Ischia, in the poem of that title, pays Comment [SW2]: I think an endnote is needed here, explaining that James elaborates on his notion of 'Interest' in a letter to H.G. Wells etc. it the tribute: 'How well you correct/ our injured eyes, how gently you train us to see/ things and men in perspective/ underneath your uniform light'. ${ }^{9}$ For those very 'picturesque' aspects of the 'gloomy wrong' evoked by Hawthorne identify the extent of its aesthetic falsification, and 'commonplace prosperity' has, as he acknowledged, its merits. But, as Auden also implies, to set 'things and men' (a suggestive ordering) in the perspective of the commonplace has its limitations as well. The ‘uniform’ light that bathes his Ischian days, like the 'external' beauty and the 'public' light suffusing the Italianate landscape of 'In Praise of Limestone' (Auden Collected, 539), composed the previous month, are qualified by adjectives that hint at an insufficiency defined more fully in the poem written a decade later to mark the end of his Italian idyll, 'Good-Bye to the Mezzogiorno’:

They are without hope. The Greeks used to call the Sun He-who-smites-from-afar, and from here, where Shadows are dagger-edged, the daily ocean blue, 
I can see what they meant: his unwinking

Outrageous eye laughs to scorn any notion

Of change or escape

(Auden Collected, 642)

Such aggressively unambiguous illumination more resembles |'that light's severe excess' discerned by Shelley in The Triumph of Life, ${ }_{-}^{10}$ than any gentle training of the eye. For, as

Auden now sees, 'between those who mean by a life a/ Bildungsroman and those to whom living/ Means to-be-visible-now, there yawns a gulf' (Auden Collected, 643). His implicit critique is that the specious plenitude of sunshine imposes a relentless present tense and obliterates shades of opinion, in the uniformity of an illumination that falsely prioritises appearance over reality.

Notoriously photophobic, Auden had in 'New Year Letter' (1940) already implied the limitations of the sun's 'neutral eye', as it 'watched the earth behave' during that 'florid August' in which armies were mustering for war (Auden Collected, 197); later, 'Pleasure Island' (1948; suggested by Fire Island) observes its sun-entranced sybarites declining into a dangerously regressive otium:

\section{Afternoon is opposed}

To rhyme and reason and chamber music,

The plain sun has no use

For the printing press, the wheel... (Auden Collected, 342-3)

Auden's eventual dissatisfaction with the 'being-visible-nowness' of Italy had, in fact, been prefigured in his very first poem of grateful homage, 'In Praise of Limestone', with its frank admission that 'this land is not the sweet home that it looks' (Auden Collected, 540); for although that poem likes the look of its limestone landscape, what it chiefly celebrates is limestone’s kinship with water. Even his earlier, initially ecstatic celebration of an English 
scene, 'Look, stranger, at this island now' (1935), acknowledged that its 'leaping light' requires a subtler modulation, ending the poem, therefore, looking not at sunlit island but at a sea surface full of clouds, which 'all the summer through the water saunter' (English Auden, 158).

Water preceded light in the Genesis myth of creation, and although, as Auden noted at the end of 'First Things First', life is possible without love, it becomes impossible without water. This fact may be what prompted Philip Larkin to take the element as essential to his constructed religion, in the poem 'Water', with its drolly parodic take on Christianity. He insists that the faithful should get thoroughly wet, and in his imagined church he replaces the altar, proposing instead to 'raise in the east/ A glass of water', in which 'any-angled light/ Would congregate endlessly'. ${ }^{11}$ This may foreshadow the resonating vacancy he later evoked in imagery of high windows. There is satiric potential, of course, in Larkin's raising his glass (as if saluting some deus absconditus), and a bite in his final adverb; for 'endlessly', whilst alluding to the doxological 'world without end', also admits the meaning 'pointlessly'. I note this poem, however, for its qualification of light as 'any-angled', which at first seems a tribute to light's limitless possibilities when freed from doctrinal obligation, but, again, cannot entirely be cleansed of a possible inference that this infinite refractability of light is equally a kind of infinite tractability, an inexhaustible capacity for compliance.

For while poets may be moved to celebrate the excellence of light, unremitting illumination can be oppressive in its abolition of those perceptual uncertainties in which, so often, poetry lives and moves and has its being. In Stevens, the world of unremitting illumination - 'Let the lamp affix its beam' - is associated with death; if we are indeed to 'Let be be finale of seem’ (Stevens Collected, 64), as ‘The Emperor of Ice Cream’ also enjoins, then we inhabit a world where, in the last words of 'Man Carrying Thing', 'The bright obvious stands motionless in cold' (Stevens Collected, 351), and we discover 'The 
fatality of seeing things too well' ('The Novel', Stevens Collected, 459). It is to evade 'the bright obvious' and its deadly import that poetry and its procedures exist: 'The motive for metaphor, shrinking from/ The weight of primary noon,/ The ABC of being' (Stevens Collected, 288).

If, without metaphor, we exist in what 'Note on Moonlight' defines as 'the mere objectiveness of things' (Stevens Collected, 531), we become trapped in a relationship to the world that an early poem, 'Tattoo', presents as nightmarish interconnection. 'The light is like a spider', it opens; which creature in succeeding lines 'crawls' over water and 'over the edges of the snow' to finish 'under your eyelids', where it 'spreads' 'Its two webs':

There are filaments of your eyes

On the surface of the water

And in the edges of the snow.

(Stevens Collected, 81)

There is nothing here of the delicate suggestiveness of 'the unseen eyebeam' ${ }^{12}$ Eliot would Comment [SW4]: Endnote needed of edition etc sense in the garden at Burnt Norton; instead, there is this brutally reductive form of perceptual entrapment. Kenneth Burke, in an early review of William Carlos Williams, famously described that poet as engaged in finding 'the shortest route between object and subject'; ${ }^{13}$ but the Procrustean connection described by Stevens brings forth monsters - or, at least, a spider - and seems to emphasise (pace Wordsworth) how inexquisitely the external world is fitted to the mind. Ralph Waldo Emerson, in Nature (1836), lamented that '(t)he axis of vision is not coincident with the axis of things' ${ }^{14}$ 'Tattoo', whose title analogises vision to a kind of punctural imprinting, suggests the awful opposite.

In Stevens, however, seeing is seldom believing, and perception is more than a matter of optics: 'The eye believes and its communion takes./ The spirit laughs to see the eye believe/ And its communion take' ('Extracts from Addresses to the Academy of Fine Ideas', Stevens Collected, 253). Such a pejorative view as seemingly offered by 'Tattoo' (which 
itself is, after all, a highly elaborate simile) is far from the whole story; because light, for Stevens, is often inseparable from the activity of what he called 'the most august imagination', creating that more abundant 'reality' to which laughing spirit responds. ${ }^{15}$ Toward the end of his 1943 essay ‘The Figure of the Youth as Virile Poet' he rises to resonantly post-Romantic definition:

Poetry is the scholar's art. The acute intelligence of the imagination, the illimitable resources of its memory, its power to possess the moment it perceives - if we were speaking of light itself, and thinking of the relationship between objects and light, no further demonstration would be necessary. Like light, it adds nothing, except itself. What light requires a day to do, and by day I mean a kind of Biblical revolution of time, the imagination does in the twinkling of an eye. ${ }^{16}$

In this passage, Stevens associates the imagination with light but also argues that it actually outstrips what he termed '[t]he eloquences of light's faculties' ('The Pure Good of Theory', Stevens Collected, 333): the addition of the imagination exceeds that of light.

Those familiar with his work, however, will know that his assertions of the imagination’s scope seldom strike an uncomplicatedly triumphalist note, even if the relationship between imagination and reality is often seen as implicitly antagonistic. And there is a defensiveness in that shrinking from 'the weight of primary noon' which leads to a characteristic association, in his poetry, between the imagination and artificial light such as candle-light or lamplight, combining power with vulnerability. For these manmade lightsources can dispel darkness but, equally, suggest its prowling presence beyond the range of Comment [SW7]: I wondered if you might elaborate further on this intriguing point? temporary illumination (as in Ernest Hemingway’s story, ‘A Clean, Well-lighted Place’). ‘We say God and the imagination are one.../ How high that highest candle lights the dark' ('Final Soliloquy of the Interior Paramour', Stevens Collected, 524): if the primary echo, here, is of 
Portia’s exclamation, 'How far that little candle throws his beams' (The Merchant of Venice, V.i.90), Macbeth’s ‘Out, out, brief candle’ is not altogether absent (Macbeth, V.v.23). ${ }^{17}$

The early poem, 'Valley Candle', makes this clear, as well as intimating further complexities of seeing:

My candle burned alone in an immense valley.

Beams of the huge night converged upon it,

Until the wind blew.

Then beams of the huge night

Converged upon its image,

Until the wind blew. ${ }^{18}$

Here, darkness with its antithetical 'beams' is figured as light's immense antagonist, but is actually called into being by the puny candle which organises the visual field around itself, forcing the 'huge night' to converge upon it much as Stevens's 'jar' would 'make the slovenly wilderness/ Surround' itself ('Anecdote of the Jar', Stevens Collected, 76). Retinal retention (a fact which complicates with history the apparent instantaneity of sight) endows even an afterimage with temporary power, enacted in this poem's doubling: we observe the flame, then we observe its 'image'; the repetition of this process calls into question the nature of the object/subject relation and of the act of perceiving. The poem needs to be quoted in its entirety because in it, like the candle-flame, we see, but do not see, the same thing twice.

Despite his concern with candles (an early drama was called 'Carlos among the Candles'), Stevens can and indeed does celebrate the sun in its plenitude, for example instructing us in 'Credences of Summer' to 'Trace the gold sun about the whitened sky/ Without evasion by a single metaphor' (Stevens Collected, 373); but since for him the act of cognition is inescapably metaphorical (which might prompt us to a different understanding of 'Tattoo', less as entrapment in any ineluctable modality of the visible than in the ineluctable 
modality of the verbal), such a project cannot succeed. Therefore, rather than figuring the sun and the perceiving self in an element of antagonism, exemplifying that 'war between the mind/ And sky' (Stevens Collected, 407) referred to in the coda to Notes toward a Supreme Fiction, the truer perspective is to see our metaphorical propensities as an extension of, rather than somehow antithetical to, the primal energy of the sun. Thus, his poem 'The Red Fern' analogises the diffusing light of the rising sun to the vigorous growth of a red fern, in an act of imagination that partakes of rather than competes with the originary creativity of 'The dazzling, bulging, brightest core,/ The furiously burning father-fire’ (Stevens Collected, 365). This verbalisation is a legitimate, conceptually sophisticated extension of the sun's primal power; it refutes Emerson's assertion that '(t)he sun illuminates only the eye of the man, but shines into the eye and the heart of the child' (Emerson, 10), by a closing adjuration to the 'Infant', who must move beyond believing 'it is enough in life/ To speak of what you see', to 'wait/ Until sight wakens the sleepy eye/ And pierces the physical fix of things' (Stevens Collected, 365). This instigation of imaginative activity by sunlight is also found in a touching late poem, 'The World as Meditation', conjoining primal source and a domesticated decor, where Penelope awakes to another daybreak possibly presaging Ulysses’ return: ‘A form of fire approaches the cretonnes of Penelope,/ Whose mere savage presence awakens the world in which she dwells' (Stevens Collected, 520).

The gendering of this poem, its masculine externality combining with a feminine interior, connects with the last of Stevens's works that I want to consider, 'Of Hartford in a Purple Light', which similarly but more playfully deploys light to effect transfiguration of the everyday; here at sunset rather than sunrise. I have elsewhere considered this poem in the context of Stevens's Francophilia and its particular historical moment, ${ }^{19}$ but I offer it here in illustration of the way in which prosaic Hartford, where he earned his living, is transformed by the addition of nothing but light and the imagination. The poem contrasts 'Lights 
masculine' with 'lights feminine', and observes how the sun which has journeyed 'From Havre to Hartford' now, at its going-down, adds a softening suggestiveness - a 'stage-light of the Opera' - as it subverts American reality by bathing the city in this purple light, installing what an earlier poem had called 'the beauty of innuendoes' ('Thirteen Ways of Looking at a Blackbird', Stevens Collected, 93):

A moment ago, light masculine,

Working, with big hands, on the town,

Arranged its heroic attitudes.

But now as in an amour of women

Purple sets purple round. Look, Master,

See the river, the railroad, the cathedral...

When the male light fell on the naked back

Of the town, the river, the railroad were clear.

Now, every muscle slops away.

(Stevens Collected, 226-7)

Again, it is a changing light that authorises this translation into French of a previously uncomplicated American location, transforming the mood from indicative to subjunctive. At the outset of this essay we found Dickinson registering the oppressiveness of 'Cathedral Tunes', and here in Stevens's poem 'the cathedral' is a solid structure modified by productive disestablishment. The 'light’ that interests him is not any doctrinally-inflected slant penetrating the stained glass of a high church window, but a more transient effect.

Whether the 'Look, Master' of this poem makes a covert allusion to Christopher Marlowe's 'Look, look, master, here comes two religious caterpillars', ${ }^{20}$ taken as epigraph by 'Mr Eliot's Sunday Morning Service', is uncertain; but in T.S. Eliot we have a use of light explaining the source is The Jew of Malta that is more complex, insofar as 'light' in his poetry both is and is not doctrinaire. I want to etc 
suggest that, in his verse, 'light' is more powerfully evocative, the further removed it is from purely doctrinal quantification and an association with 'Cathedral Tunes'. In some early poems, light could be connected with a quality of what I will call erotic perplexity, as when Prufrock notes how women's 'white’ 'bare’ arms are 'in the lamplight, downed with light brown hair!' (Eliot Collected, 15), or when the autocratic but emotionally baffled speaker of 'La Figlia Che Piange' instructs its female subject to 'Weave, weave the sunlight in your hair' (Eliot Collected, 36). This sense of a challenge somehow evaded is deepened, in The Waste Land (I) into an impasse as much metaphysical as erotic:

-- Yet when we came back, late,

From the hyacinth garden,

Your arms full, and your hair wet, I could not

Speak, and my eyes failed, I was neither

Living nor dead, and I knew nothing,

Looking into the heart of light, the silence. (Eliot Collected, 64)

This, bordering as it does on the otherworldly, might correspond to Eliot's analysis of the Vita Nuova as a form of 'sublimation' - 'to look to death for what life cannot give'. Such a sense of the insufficiency of the simply given order, moving through the faux-classical 'Sunlight on a broken column' and the sarcastically diminished 'twinkle of a fading star' ('The Hollow Men', Eliot Collected, 90), ushers toward some of the more overtly religious imagery of light increasingly encountered in his work. There is, of course, a long tradition of using light in such a context, reaching back through Henry Vaughan’s vision of 'Eternity', 'Like a great Ring of pure and endless light', ${ }^{21}$ to Eliot's acknowledged master, Dante, of whose 'last and greatest canto' (Paradiso XXXIII) he wrote in 1929: 'Nowhere in poetry has experience so remote from ordinary experience been expressed so concretely, by a masterly use of the imagery of light which is the form of certain types of mystical experience'.22 
Eliot's overt embrace of Dante seems as emphatic as, earlier, had been his overt rejection of Romanticism: the pockmarked moon of ‘Rhapsody on a Windy Night' (1915) sourly revisits a favoured Romantic trope, and its line 'I could see nothing behind that child's eye' (Eliot Collected, 27) expresses a double repudiation of visionary potential, in both poet and child, as well as of the stance of Wordsworth's 'Immortality Ode' or notions of seeing into the life of things. Yet I use the term 'overt', because it has been noticed (by Randall Jarrell, C.K. Stead and Michael O’Neill, among others) that Eliot’s covert attitudes were less absolutely demarcated. When, for example, he defines ‘the auditory imagination’ as 'penetrating far below the conscious levels of thought and feeling (...), returning to the origin and bringing something back', or in a subsequent lecture gratefully evokes 'the depths of feeling into which we cannot peer, ${ }^{23}$ he situates himself in the vicinity of that Coleridge who sought a 'symbolical language for something within me that already and forever exists', and whose ghost summons him at the very end of his lecture-series.

Whatever he owed to Romanticism, it appears that the Dantean example could lead Eliot in two directions: emulating the systematisation of Dante resulted in a potentially overformulated and dogmatic imagery of light; emulating his more mystical aspects could by contrast produce such a beautifully unfathomable line as 'White light folded, sheathed about her, folded' (Eliot Collected, 100), from Ash-Wednesday (IV), or the flash of the kingfisher in Burnt Norton. In some of the 'Choruses from The Rock', however, we meet Eliot's most extended use of light imagery in his verse with less happy results. In the seventh Chorus, Eliot starts with the creation myth, developing thence a dogmatic categorisation, 'And men who turned towards the light and were known of the light/ Invented the Higher Religions; and the Higher Religions were good / And led men from light to light, to knowledge of Good and Evil' (Eliot Collected, 176). This forward march reached a limit, however, until the moment of Incarnation provided 'the light of the Word' (Eliot Collected, 177). The doctrinal aspects 
of light amass, as the focus moves toward the purpose of this pageant, The Rock, which was to build new churches in London's expanding suburbs; the Chorus evokes the 'formed stone', 'visible crucifix’ and 'dressed altar', behind which the east window's 'lifting light' acts as ‘The visible reminder of Invisible Light’ (Eliot Collected, 182).

In the final chorus's ensuing paean to light, Eliot emphasises the physical world of 'visible' light as foreshadowing the inapprehensible world beyond (the greater 'Light Invisible' that is 'Too bright' for any 'mortal vision'):

O Greater Light, we praise Thee for the less;

The eastern light our spires touch at morning,

The light that slants upon our western doors at evening,

The twilight over stagnant pools at batflight,

Moon light and star light, owl and moth light,

Glow-worm glowlight on a grassblade.

(Eliot Collected, 184)

This partial reconciliation with earthly varieties of luminary experience provokes gratitude: 'Therefore we thank Thee for our little light, that is dappled with shadow' (Eliot Collected, 185). These lines sound rather too much like Eliot resembling himself, to be truly effective poetry; but if I find here, as some contemporaries did then, an oppressive 'Heft/ Of Cathedral Tunes' in an over-thematised structure, his closing nod toward shadow-dappled light emphasises the features that Eliot, in common with the other poets I have touched on, deploys to best effect: also glimpsed in this Chorus when - revisiting his potently suggestive undersea imaginary - Eliot evokes a 'submarine' gaze that, looking upward, sees ‘the light that fractures through unquiet water’ (Eliot Collected, 184).

Burnt Norton, also written during the mid-1930s, is suffused with the uncertainties of light and the semi-accidental nature of illumination; it is also concerned with the interimplication of light and darkness, one suggesting the possibility of the other so that the way 
up and the way down may indeed be the same: drafts of this poem, Lyndall Gordon has noted, closed with the words 'Light/ Gone'. ${ }^{24}$ The moment when 'the pool was filled with water out of sunlight,/(...)The surface glittered out of heart of light' is more effective for being inexplicable, as too is the 'grace of sense, a white light still and moving' with which it is associated (Eliot Collected, 190, 191). 'The distraction fit, lost in a shaft of sunlight' (Eliot Collected, 213), as the moment is recuperated in The Dry Salvages, although conscripted to the overall thematic structure of Four Quartets, retains even within that function its aspect of fortuity, a sense that pattern is apprehended rather than constructed. This was the implication of an aside offered by Eliot in his 1934 essay on the dramatist John Marston: 'as we familiarize ourselves with the play we perceive a pattern behind the pattern into which the characters deliberately involve themselves; the kind of pattern which we perceive in our own lives only at rare moments of inattention and detachment, drowsing in sunlight' (Selected Essays, 232).

Such rare moments of detachment, when something comes unbidden, are characteristic of Eliot's most productive light-effects; and as with the other poets discussed in this essay, an illumination other than that of Hawthorne's 'broad and simple daylight' is the most suggestive. 'Please, will you/ Give us a light?' (Eliot Collected, 140), asks a sardonic voice at the end of 'Triumphal March', but too much light for too long would be poetically problematical, disabling such transient effects as when, in Eliot, light is 'sad' (The Waste Land) or 'sultry' (East Coker); 'Cover me over, light-in-leaves' (Eliot Collected, 152), from 'New Hampshire', evokes the authentically fugitive chiaroscuro. For, like Stevens's 'necessary angel’, which declares ‘quickly, too quickly, I am gone’ (Stevens Collected, 497), evanescence is of the essence of such moments of illumination; so that, in Little Gidding, the truer note may be sounded, not by the summative 'And the fire and the rose are one', but in the transitional 'while the light fails/ On a winter’s afternoon' (Eliot Collected, 222). This 
itself reprises an earlier shadow-dappled moment in East Coker, when light, adding or subtracting nothing but itself, accrues mysterious agency, simultaneously everyday and otherworldly:

\section{Now the light falls}

Across the open field, leaving the deep lane

Shuttered with branches, dark in the afternoon,

Where you lean against a bank while a van passes,

And the deep lane insists on the direction

Into the village, in the electric heat

Hypnotised.

(Eliot Collected, 196)

The co-operative interaction with the world that is the case - that banal 'van' - seems to conduce to a transfiguration, through the echoic conjunction 'And' enforcing its ultra-logical connection, whereby the 'deep lane' at its second mention is becoming richer and stranger. In this effect, assonantal triads ('field’, 'leaving', 'deep'; 'branches’, 'dark', 'afternoon’; 'bank', 'van', 'And') followed by the diminishing sequence of 'insists', 'into' and 'in', play their part. This lane, with its invitingly purposive darkness, knows more than we do, knows where we should go: toward the village where, as will soon be seen, past and present intermingle and broad daylight goes into abeyance. |'The sad ghost of Coleridge beckons to me from the shadows': with these words Eliot had closed The Use of Poetry and the Use of Criticism Comment [SW12]: Page number needed (156), intending, I suppose, a dying fall. But I hope to have suggested that 'the shadows' need not denote the end of poetry, but its potentially productive source. 'In my end is my beginning', therefore; for, as Michael Symmons Roberts has observed, 'To be alive is to throw shadows./ No mere ghost could obstruct the light/ like we do'. ${ }^{25}$ 


\section{Tony Sharpe, Lancaster University}

a.sharpe@lancaster.ac.uk

\footnotetext{
${ }^{1}$ I cite Thomas H. Johnson's edition of The Complete Poems of Emily Dickinson (London, 1970). All poems are also accessible online at the Emily Dickinson Archive (http://www.edickinson.org/), as are their different versions in the later Franklin edition which assigns them different numbers. For ease of reference I give numbers for both editions (' $\mathrm{J}$ ' and ' $\mathrm{F}$ '), which can be used to locate these texts in the Archive.

${ }^{2}$ Thomas Hardy: The Complete Poems, ed. James Gibson (London, 1976), 12.

${ }^{3}$ Stevens's poetry will be cited (with one exception) from The Collected Poems of Wallace Stevens (London,
} 1955). See 'An Ordinary Evening in New Haven' (XXIV), 482.

${ }^{4}$ Coleridge: Select Poetry and Prose, ed. Stephen Potter (London, Nonesuch Press, no date), 175.

5 'Tree at My Window', The Poetry of Robert Frost, ed. Edward Connery Lathem (London, 1972), 252.

6 'We cannot imagine stories in Eden': see Michael Edwards, Towards a Christian Poetics (London, 1984), 72-3.

${ }^{7}$ Nathaniel Hawthorne, The Marble Faun, ed. Susan Manning (Oxford, 2002), 4.

${ }^{8}$ In his essay on 'The New Novel', James complained of Arnold Bennett's fiction that it provided 'all the circumstances of interest', but 'where is the interest itself?'; Notes on Novelists (New York, 1914), 326.

${ }^{9}$ Auden's poetry will be cited from the following sources: Collected Poems, ed. Edward Mendelson (London, 2007) and The English Auden, ed. Edward Mendelson (London, 1978). This quotation, Auden Collected, 541.

${ }^{10}$ Percy Bysshe Shelley: The Major Works, eds. Zachary Leader and Michael O'Neill (Oxford, 2003), 617.

${ }^{11}$ Philip Larkin, The Whitsun Weddings (London, 1971), 20.

${ }^{12}$ Eliot's poetry will be cited from his Collected Poems, 1909-1962 (London, 1970). This quotation, 190

13 'Heaven's First Law', Dial, 72 (January to June, 1922), 198.

${ }^{14}$ Nature, in Emerson: Essays and Lectures ('The Library of America', Cambridge, 1983), 47.

15 'Reality Is an Activity of the Most August Imagination' is the title of a Stevens poem, in Opus Posthumous.

${ }^{16}$ Wallace Stevens, The Necessary Angel: Essays on Reality and the Imagination (New York, 1951), 61-2.

${ }^{17}$ I cite the Alexander Text of Complete Works of Shakespeare (London and Glasgow, 1951).

${ }^{18}$ I cite the version first published in Others: $A$ Number for the Mind's eye Not to be read aloud (December 1917), 25. 'Valley Candle' and 'Tattoo' are easily accessible at various online locations.

${ }^{19}$ See Tony Sharpe, 'Cultural Immaterialism: Wallace Stevens in Virtual Paris', Key Words, 12 (Autumn 2014), 108-24.

${ }^{20}$ See The Jew of Malta, IV. 1529.

${ }^{21}$ 'The World', in The Metaphysical Poets, ed. Helen Gardner (Harmondsworth, 1957), 271.

${ }^{22}$ Prose quotations in this paragraph come from T.S. Eliot, Selected Essays (London, 1951), 275, 267.

${ }^{23}$ T.S. Eliot, The Use of Poetry and the Use of Criticism (London, 1964), 118-19, 148.

${ }^{24}$ See Lyndall Gordon, T.S. Eliot: An Imperfect Life (New York, 2000), 630 (note to p. 345).

${ }^{25}$ Michael Symmons Roberts, 'In Praise of Flaking Walls', Drysalter (London, 2013), 117. 